\title{
Which Fungus Originally was Trichophyton mentagrophytes? Historical Review and Illustration by a Clinical Case
}

\author{
Annemay Chollet • Vincent Cattin • \\ Marina Fratti $\cdot$ Bernard Mignon $\cdot$ Michel Monod
}

Received: 16 January 2015/Accepted: 14 April 2015/Published online: 26 April 2015

(C) European Union 2015

\begin{abstract}
Several dermatophytes producing numerous pyriform or round microconidia were called Trichophyton mentagrophytes. Among these dermatophytes are the teleomorph species Arthroderma benhamiae, Arthroderma vanbreuseghemii and Arthroderma simii, and other species such as Trichophyton interdigitale, Trichophyton erinacei and Trichophyton quinckeanum for which only the anamorph is known. Confusion exists about which fungus should be really called T. mentagrophytes and about the rational use of this name in practice. We report a case of beard ringworm (tinea barbae) with $A$. vanbreuseghemii. According to both clinical signs and the type of hair parasitism, this case was exactly compatible to the first description of a non-favic dermatophytosis by Gruby under the name of "mentagrophyte" from which was
\end{abstract}

A. Chollet $\cdot$ M. Fratti $\cdot$ M. Monod ( $₫)$

Laboratoire de Mycologie, BT422, Service de

Dermatologie, Centre Hospitalier Universitaire Vaudois,

1011 Lausanne, Switzerland

e-mail: Michel.Monod@chuv.ch

V. Cattin

Dermatology Private Practice, 2000 Neuchâtel,

Switzerland

B. Mignon

Veterinary Mycology, Department of Infectious and Parasitic Diseases, Fundamental and Applied Research for Animals and Health (FARAH), Faculty of Veterinary Medicine, University of Liège, B-43 Sart-Tilman, 4000 Liège, Belgium derived the dermatophyte epithet mentagrophytes. In addition, the phenotypic characters of the isolated fungus in cultures perfectly matched with those of the first description of a dermatophyte under T. mentagrophytes by Blanchard (Parasites animaux et parasites végétaux à l'exclusion des Bactéries, Masson, Paris, 1896). In conclusion, T. mentagrophytes corresponds to the fungus later named A. vanbreuseghemii. However, because the neotype of $T$. mentagrophytes was not adequately designated in regard to the ancient literature, we would privilege the use of $A$. vanbreuseghemii and abandon the name of $T$. mentagrophytes.

Keywords Dermatophytes - Tinea barbae . Trichophyton mentagrophytes $\cdot$ Arthroderma vanbreuseghemii $\cdot$ History

\section{Introduction}

Several dermatophytes producing numerous pyriform or round microconidia, but differing in ecological preference, were regrouped under the name of Trichophyton mentagrophytes by Emmons [1]. Among these dermatophytes, mating experiments and ribosomal DNA sequencing revealed different teleomorph zoophilic species, among which are Arthroderma benhamiae, Arthroderma vanbreuseghemii and Arthroderma simii, and other species for which only the anamorph is known, such as Trichophyton interdigitale (anthropophilic), Trichophyton erinacei and Trichophyton 
quinckeanum (zoophilic) [2-5]. T. mentagrophytes is still currently used in practice to name dermatophytes both in laboratories and by practitioners.

We report a case of beard ringworm (tinea barbae) with a dermatophyte in the $T$. mentagrophytes complex subsequently identified by sequence analysis as Arthroderma vanbreusghemii in a 32-year-old man who was recently presented at the Dermatology Department of the Centre Hospitalier Universitaire Vaudois (CHUV, Lausanne, University Hospital). This case was found of interest as it is compatible to the first description of a non-favic dermatophytosis by Gruby under the name of "mentagrophyte" from which was derived the dermatophyte epithet (species name) "mentagrophytes" for dermatophytes producing numerous pyriform or round microconidia.

\section{Case Report}

The patient presented with a 2-week history of pruritic lesions involving the mental (chin) region with extension on the basis of the nose (Fig. 1). This infection was typically a "sycosis" (papulopustular inflammation of the hair follicle). Physical examination revealed erythematous plaques with follicular pustules and yellow crusts. No lymphadenopathy was present. Direct mycological examination of purulent material and scales showed high numbers of septate filaments and arthrospores.

Culture assay for 7 days at $32{ }^{\circ} \mathrm{C}$ on Sabouraud's agar medium produced a growing fungus with a white to beige powdery surface attesting to the production of

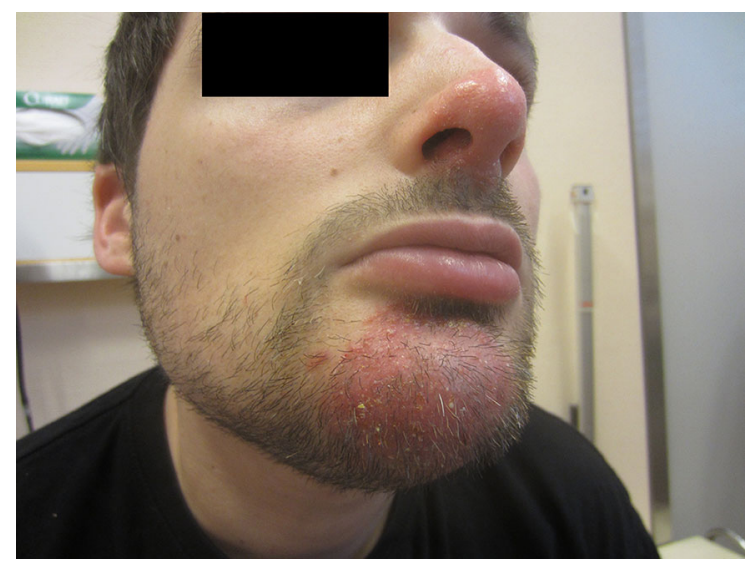

Fig. 1 Tinea barbae with A. vanbreuseghemii numerous pyriform microconidia (Fig. 2). Following its macroscopic and microscopic characters, the fungus was identified as a species belonging to the $T$. mentagrophytes species complex. Fungal genomic DNA was isolated, and part of the $28 \mathrm{~S}$ ribosomal DNA, as well as the internal transcribed spacer (ITS) region of the ribosomal DNA, was subsequently amplified by polymerase chain reaction (PCR) as previously described [4]. The sequences of the PCR products were found to be $100 \%$ identical to the sequences AF378740 and AF506034, respectively. The patient was treated with a topical and oral terbinafine $(250 \mathrm{mg} / \mathrm{d})$ therapy during 2 months and totally cured.

\section{Discussion}

Beard ringworm (tinea barbae) is typically a dermatophytosis of men, particularly farm workers. It is mostly caused by Trichophyton verrucosum from the direct or indirect spread of infection from cattle. Cases of tinea barbae caused by $T$. mentagrophytes were previously reported in the literature, but the fungus was only identified by phenotypic examination of cultures $[6,7]$. In the present case, PCR and DNA sequencing allowed the identification of the infecting fungus as being A. vanbreuseghemii in addition to culture morphological features. The nucleotide sequence of a part of the $28 \mathrm{~S}$ ribosomal DNA, as well as the ITS region of the ribosomal DNA, was identical to those of the A. vanbreuseghemii strains frequently isolated from hunting cats and dogs [4, 8]. A. vanbreuseghemii is a zoophilic dermatophyte species
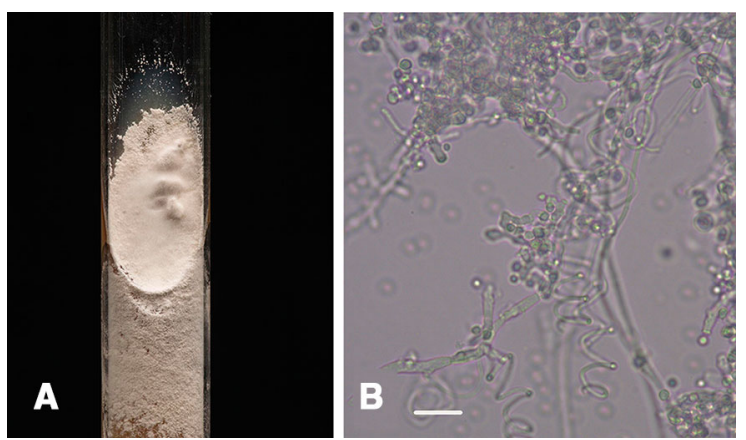

Fig. 2 a Culture of the isolated fungus (A. vanbreuseghemii). b Microscopic characters of the fungus producing numerous microconidia and spiral hyphae (Bar $10 \mu \mathrm{m})$ 
that has been clearly delineated of the closely related anthropophilic species $T$. interdigitale which causes non-inflammatory tinea pedis (foot mycosis) and tinea unguium (onychomycosis). Indeed, confrontations (mating experiments) between $T$. interdigitale isolates and A. vanbreuseghemii isolates of the opposite mating type do not allow the production of fertile cleistothecia [4]. Of important note, $T$. interdigitale was extended by German authors to contain zoophilic strains similar to the fungus of the present case report in addition to anthropophilic strains $[9,10]$. In this way, the " $T$. interdigitale zoophilic strains" correspond to A. vanbreuseghemii.

This case report was found of interest and raised our attention because it enlightens on "Which fungus originally was T. mentagrophytes?" The dermatophyte species name mentagrophytes is derived from the French name "mentagre," created in 1842 by Gruby [11] when he first described a non-favic dermatophytose in a beard. "Mentagrophyte" literally means "plant of the chin," with a Latin and Greek etymology ("mentum" for chin, $\alpha \gamma \rho \alpha$ for catching and $\varphi v \tau o v$ for plant). In his very succinct description, Gruby reported a fungus causing a non-favic infection where the fungal elements formed a continuous sheath around the hair (ectothrix parasitism). The fungus was termed Microsporon mentagrophytes 11 years later by Robin [12], who first used the term of mentagrophytes as a species name. Like Gruby, Robin only gave a clinical description of the fungal infection with no additional details about the morphology of the fungus. The transfer of Microsporon mentagrophytes in the genus Trichophyton (Malmsten, 1845) was made by Blanchard [13]. This author described a fungus with an "extreme vitality" in culture. The culture was white and was "recovered by a white dust made by conidia." The succinctness of the description made by Gruby was raised by Sabouraud [14] in his treatise, "Les teignes." For Sabouraud, the fungus described by Gruby was an ectothrix Trichophyton to which belong the "Trichophyton microides" and the "Trichophyton megaspores" which were differentiated by the size and the arrangement of parasitic arthrospores around the hair observed by direct mycological examination of clinical samples. The "Trichophyton microides" encompassed various species included in T. mentagrophytes by Emmons in 1934, while the "Trichophy- ton megaspores" contained various species now considered as a synonym of T. verrucosum.

The case described in the present communication is perfectly compatible to the first description of a nonfavic dermatophytosis by Gruby [11] according to both clinical signs and the type of hair parasitism. It is also compatible with the description of T. mentagrophytes by Blanchard, who described a species producing numerous pyriform or round microconidia in culture [13]. Identification of the dermatophyte species responsible for this sycosis as A. vanbreuseghemii gives support to a response to the question about which fungus should be really called T. mentagrophytes. A confusion came from the recent choice of the dermatophyte strain CBS 318.56 isolated from a human suppurative infection to designate a neotype of T. mentagrophytes [15]. The ITS and 28S sequences of this neotype strain were found to be identical to those of T. quinckeanum, which is an agent of smouse and human favus [5, 16] while, based on Gruby's description, T. mentagrophytes senso stricto should have been reserved for a dermatophyte causing a sycosis. One case of tinea barbae was recently described with A. benhamiae [17]. However, in most cases, the reservoir of this nowadays emerging species is guinea pigs [8], and it must be considered that people in the nineteenth century had no guinea pigs as pets.

Why do we call the fungus of the present case report A. vanbreuseghemii? The genus name Arthroderma is used for the dermatophytes species when a sexual form (teleomorph) has been obtained. In the T. mentagrophytes complex, this change of nomenclature concerns three zoophilic species: A. benhamiae, A. vanbreuseghemii and $A$. simii (Table 1). Mating experiments revealed that $A$. benhamiae and $A$. vanbreuseghemii harbor several phenotypes and genotypes. For species whose teleomorph is still unknown, the genus name "Trichophyton" is employed (Table 1). According to the rules proposed by the Amsterdam declaration on Fungal Nomenclature (one fungus $=$ one name) $[18]$, the name $T$. mentagrophytes should simply disappear on behalf of $A$. vanbreuseghemii. However, according to the same declaration, "authors should choose the oldest generic name, irrespective of whether it is typified by a species name with a teleomorphic or an anamorphic type, 
Table 1 Dermatophyte species producing numerous microconidia in cultures and previously named Trichophyton mentagrophytes

\begin{tabular}{|c|c|c|c|c|}
\hline Teleomorph $^{\mathrm{a}}$ & Anamorph ${ }^{\circ b}$ & Main animal reservoir & ITS sequences $^{c}$ & References \\
\hline $\begin{array}{l}\text { A. } \\
\text { vanbreuseghemii }\end{array}$ & Previously called T. mentagrophytes ${ }^{\mathrm{e}}$ & Cats, dogs, rodents (mice, chinchillas) & $\begin{array}{l}\text { AF506034 } \\
\text { GU646873 } \\
\text { GU646874 } \\
\text { GU646879 } \\
\text { GU929694 } \\
\text { AF170452 }\end{array}$ & {$[4,24]$} \\
\hline Unknown & T. interdigitale & -(Anthropophilic) & $\begin{array}{l}\text { AF506033 } \\
\text { AF506036 } \\
\text { EU181446 }\end{array}$ & [20] \\
\hline A. benhamiae & Not attributed ${ }^{\mathrm{d}}$ & $\begin{array}{l}\text { Guinea pigs but also a wider range } \\
\text { of hosts (dogs, rabbits, degus) }\end{array}$ & $\begin{array}{l}\text { AB088677 } \\
\text { AB048192 } \\
\text { AY315661 }\end{array}$ & {$[19,26-28]$} \\
\hline Unknown & T. erinacei & Hedgehogs & Z97996 & {$[25,26]$} \\
\hline A. simii & Previously called $T$. simii & Monkeys, poultry, dogs & $\begin{array}{l}\text { JQ407209 } \\
\text { JQ407210 }\end{array}$ & {$[5,29]$} \\
\hline Unknown & T. quinckeanum & Mice (favus) & $\begin{array}{l}\text { A4185126 } \\
\text { Z97995 }\end{array}$ & {$[5,16]$} \\
\hline
\end{tabular}

The names in bold should be privileged for these species

a Sexual form of the fungus

b Asexual or conidial form of the fungus

c AF606034 in the present case report

d Anamorph name other than T. mentagrophytes not formally given for A. benhamiae

e The use of A. vanbreuseghemii is privileged, and the name of T. mentagrophytes is abandoned

except where the younger generic name is far better known." In the present case, it might be argued that $T$. mentagrophytes is both older and better known, in which case $A$. vanbreusghemii should be abandoned. A problem is that the neotype of T. mentagrophytes was not adequately designated in regard to the ancient literature and refers to a dermatophyte species that is different from a mycological, clinical and epidemiological perspective. In addition, an anamorph name other than $T$. mentagrophytes does not exist for A. benhamiae, and consequently, T. mentagrophytes and $A$. benhamiae would be the names retained for two closely related but distinct dermatophytes species for which the teleomorph is known [2-4, 19]. We would therefore privilege the use of $A$. vanbreuseghemii and abandon the name of $T$. mentagrophytes as $A$. vanbreusghemii is at present used by many authors in several countries [20-22]. Moreover, if both anamorph and teleomorph names have been widely used, the teleomorph name is to be maintained unless a formal application in favor of the anamorph name has been made [23].

\section{References}

1. Emmons CW. Dermatophytes: natural groupings based on the form of the spores and accessory organs. Arch Dermatol Syphilol. 1934;30:337-62.

2. Ajello L, Cheng SL. The perfect state of Trichophyton mentagrophytes. Sabouraudia. 1967;5:230-4.

3. Takashio M. Une nouvelle forme sexuée du complex Trichophyton mentagrophytes, Arthroderma vanbreuseghemii sp. nov. Ann Parasitol Hum Comp. 1973;48:713-32.

4. Symoens F, Jousson O, Planard C, et al. Molecular analysis and mating behaviour of the Trichophyton mentagrophytes species complex. Int J Med Microbiol. 2011;301:260-6.

5. Beguin H, Pyck N, Hendrickx M, et al. The taxonomic status of Trichophyton quinckeanum and T. interdigitale revisited: a multigene phylogenetic approach. Med Mycol. 2012;50:871-82.

6. Kick G, Korting HC. Tinea barbae due to Trichophyton mentagrophytes related to persistent child infection. Mycoses. 1998;41:439-41. 
7. Bonifaz A, Ramírez-Tamayo T, Saúl A. Tinea barbae (tinea sycosis): experience with nine cases. J Dermatol. 2003;30:898-903.

8. Drouot S, Mignon B, Fratti M, et al. Pets as the main source of two zoonotic species of the Trichophyton mentagrophytes complex in Switzerland, Arthroderma vanbreuseghemii and Arthroderma benhamiae. Vet Dermatol. 2008;20:13-8.

9. Nenoff P, Herrmann J, Gräser Y. Trichophyton mentagrophytes sive interdigitale? A dermatophyte in the course of time. J Dtsch Dermatol Ges. 2007;5:198-202.

10. Nenoff P, Handrick W, Krüger C, et al. Dermatomykosen durch Haus- und Nutztiere: Vernachlässigte Infektionen? Hautarzt. 2012;63:848-58.

11. Gruby D. Sur une espèce de mentagre contagieuse résultant du développement d'un nouveau cryptogame dans la racine des poils de la barbe de l'homme. C R Acad Sci. 1842;15:512-4.

12. Robin C, editor. Microsporon mentagrophytes. In: Histoire naturelle des végétaux parasites qui croissent sur l'homme et les animaux vivants. Paris: Baillière; 1853. p. 430-6.

13. Blanchard R. Parasites animaux et parasites végétaux à l'exclusion des Bactéries. In: Bouchard C, editor. Traité de pathologie générale. Paris: Masson; 1896. p. 811-926.

14. Sabouraud R. Les teignes. Paris: Masson; 1910.

15. Gräser Y, Kuijpers AF, Presber W, De Hoog GS. Molecular taxonomy of Trichophyton mentagrophytes and T. tonsurans. Med Mycol. 1999;37:315-30.

16. Blank F. Favus of mice. Can J Microbiol. 1957;3:885-96.

17. Braun SA, Jahn K, Westermann A, et al. Tinea barbae profunda durch Arthroderma benhamiae. Eine diagnostische Herausforderung. Hautarzt. 2013;64:720-2.

18. Hawksworth DL, Crous PW, Redhead SA, et al. The Amsterdam declaration on fungal nomenclature. IMA Fungus. 2011;2:105-12.
19. Symoens F, Jousson O, Packeu A, et al. The dermatophyte species Arthroderma benhamiae: intraspecies variability and mating behavior. J Med Microbiol. 2013;62:377-85.

20. Kano R, Nakamura Y, Watari T, et al. Molecular analysis of chitin synthase 1 (CHS1) gene sequences of Trichophyton mentagrophytes complex and T. rubrum. Curr Microbiol. 1998;37:236-9.

21. Kano R, Hasegawa A. Historic topics on classification of Trichophyton mentagrophytes complex. Med Mycol J. 2014;55:73-7.

22. Zhang H, Ran Y, Liu Y, et al. Arthroderma vanbreuseghemii infection in three family members with kerion and tinea corporis. Med Mycol. 2009;47:539-44.

23. de Hoog GS, Chaturvedi V, Denning DW, et al. Name changes in medically important fungi and their implications for clinical practice. J Clin Microbiol. 2015;53:1056-62.

24. Ninet B, Jan I, Bontems O, Léchenne B, et al. Identification of dermatophyte species by $28 \mathrm{~S}$ ribosomal DNA sequencing with a commercial kit. J Clin Microbiol. 2003;41:826-30.

25. Gräser Y, El Fari M, Vilgalys R, et al. Phylogeny and taxonomy of the family Arthrodermataceae (dermatophytes) using sequence analysis of the ribosomal ITS region. Med Mycol. 1999;37:105-14.

26. Fumeaux J, Mock M, Ninet B, et al. First report of Arthroderma benhamiae in Switzerland. Dermatology. 2004;208:244-50.

27. Sieklucki U, Oh SH, Hoyer LL. Frequent isolation of Arthroderma benhamiae from dogs with dermatophytosis. Vet Dermatol. 2014;25:39-e14.

28. Hiruma J, Kano R, Harada K, et al. Occurrence of Arthroderma benhamiae genotype in Japan. Mycopathologia. 2015;179:219-23.

29. Beguin H, Goens K, Hendrickx M, et al. Is Trichophyton simii endemic of the Indian subcontinent? Med Mycol. 2013;51:444-8. 